\title{
Recruiting and Retaining Members in Agricultural Organizations ${ }^{1}$
}

\author{
Ricky Telg ${ }^{2}$
}

\section{Introduction}

Many organizations, including agricultural associations, struggle with recruiting new members and retaining current members. The University of Florida Institute of Food and Agricultural Sciences' Center for Public Issues Education in Agriculture and Natural Resources (UF/IFAS PIE Center) conducted membership surveys of the Florida Cattlemen's Association (FCA) (UF/IFAS PIE Center, 2010) and Florida CattleWomen (FCW) (Oesterreicher, 2016) to aid both groups in their membership efforts. A web-based survey was sent to 1,771 current and former FCA members, with 556 responding (32\% response rate). Similarly, a slightly different web-based survey was sent to 754 current and former FCW members, with 101 responding (13.3\% response rate). In both studies, barriers to membership were identified, and common practices emerged relating to how both organizations were recruiting new members and retaining current members. These barriers and practices will be discussed in this publication to help agricultural organizations be better equipped to attract new members and keep current members.

\section{FCA and FCW Membership Benefits}

Survey respondents for both organizations noted that they became members to support the beef industry through political representation (FCA), promotional activities (FCW), or educational opportunities (FCA, FCW). Respondents said they enjoyed the networking and professional development opportunities provided by both organizations.

\section{FCA and FCW Membership Barriers}

Respondents were asked to specify barriers to joining the FCA or FCW organizations. The most frequent response was that potential members to either organization-individuals who had cattle, worked in an affiliated industry, or were identified as being interested in the cattle industrysimply had never been asked to join. FCW respondents also noted that people did not have enough time to devote to becoming a member.

Former members were asked why they did not remain as members. The most frequent response was that they forgot to renew their membership. Other reasons included were that the organizations were cliquish (FCA, FCW), the organization focused only on large cattle operations (FCA), and membership was not valuable (FCA, FCW).

FCW member respondents noted that they were also members in several other organizations. Seventy-four percent were members of another agricultural organization. Of that, $54 \%$ were members of one or two other organizations, $38 \%$ were members of three to four other groups, and $8 \%$ were members of five or more. Eighty-one percent were also members of non-agriculture organizations, such as civic, church, or business organizations. Forty-one percent held

1. This document is AEC637, one of a series of the Department of Agricultural Education and Communication, UF/IFAS Extension. Original publication date March 2018. Visit the EDIS website at http://edis.ifas.ufl.edu.

2. Ricky Telg, professor, Department of Agricultural Education and Communication; UF/IFAS Extension, Gainesville, FL 32611.

The Institute of Food and Agricultural Sciences (IFAS) is an Equal Opportunity Institution authorized to provide research, educational information and other services only to individuals and institutions that function with non-discrimination with respect to race, creed, color, religion, age, disability, sex, sexual orientation, marital status, national origin, political opinions or affiliations. For more information on obtaining other UF/IFAS Extension publications, contact your county's UF/IFAS Extension office. 
leadership positions in the other agriculture organizations, and $33 \%$ were leaders in non-agriculture groups.

\section{Recruiting and Retaining Members}

These results point to some specific areas that agricultural organizations can use to enhance their membership recruitment and retention efforts.

- Know and state your purpose. No agricultural organization can be everything to everybody. Although the two cattle organizations had a lot of activities, respondents consistently noted the primary reason they joined was to support the beef industry through particular efforts, such as promotional activities. In your organization, it is important to identify what it is that you do-and do well-and then focus efforts in this area. For instance, an organization could provide excellent networking, educational activities, and/or professional development, all of which could be of great value to current and potential members. The more focused you are on an organization's purpose, the better you will be able to communicate the purpose to prospective members and to reinforce it to current members.

\section{- Provide networking and professional development} opportunities. These activities were major reasons FCA and FCW members continued membership in their respective organizations. Activities in these areas could include touring related businesses, holding educational seminars, or getting together for meals.

\section{- Avoid creating an unwelcoming environment at} meetings. Some survey respondents noted that they experienced an unwelcoming environment at meetings, which influenced them not to rejoin. They said that attending unwelcoming meetings, especially local or chapter meetings where many people knew each other but were not welcoming to new people who were not as well-connected, was a major factor in deciding to end their membership. Following are some suggestions to help overcome an unwelcoming meeting environment:

- Something as simple as having everyone wear nametags - not just guests - can help alleviate fear from new attendees. If you see someone new at a meeting, take it upon yourself to introduce yourself, and then introduce the new person to others. In order to make people feel welcome, FCW initiated regional social events where members were encouraged to bring a friend. The first event, due to its successful attendance and program, was featured on the FCA magazine's cover.
- Organizations frequently hold meetings at restaurants, and if the restaurant features expensive meals, some members may not be able to afford pricey food. If your organization is reaching out to new members who are just starting out in their business, they may not be able to afford these types of meals, so consider all of the costs people have to pay in addition to membership dues.

- When someone attends, follow up with email or a phone call. People want to feel wanted, so let them know you enjoyed meeting them.

- Consider members' time constraints. Time commitments and constraints are major factors in why people consider joining an organization. After receiving the study's results, FCW leaders opted to re-prioritize the amount of time members contributed to the organization. FCW activities were moved to weekends with shorter volunteer work shifts to be more "time-friendly."

- Groom leaders. In order to encourage new leaders in organizations, ease them into leadership positions, possibly through committee work. Consider a mentorship program for emerging leaders.

- Communicate effectively and frequently. One of the reasons FCA and FCW members did not rejoin was because they forgot to renew and did not receive notices from their organizations to renew. Communicate regularly with members regarding renewing their membership. Also, consider identifying how your members like to receive information from your organization. Is it through social media? Is it through conventional emails? Is it through a newsletter? In many situations, you will find that a sizeable percentage of your members will like to be communicated with in multiple ways, so consider using a multi-prong communication effort, too.

- Determine how you measure "success." Determining "success" may be difficult to measure, but it is important to consider. Does "success" mean attaining more members, more leaders, or more involvement from members? To help you determine what "success" looks like, consider tying your definition of success to your organization's purpose. In essence, your purpose guides you in your assessment of success.

\section{Summary}

By incorporating some of the recommended practices, your agricultural organization will be better equipped to overcome barriers to membership, attract new members, and keep current members. 


\section{References}

Oesterreicher, S. (2016). Examining membership within the Florida CattleWomen, Inc. in order to increase membership. Unpublished undergraduate honors thesis. Retrieved from http://ufdc.ufl.edu/AA00046787/00001?search=oesterreich er

UF/IFAS Center for Public Issues Education in Agriculture and Natural Resources (2010). Florida Cattlemen's Association membership survey. Retrieved from http:// www.piecenter.com/wp-content/uploads/2015/09/FCAMembership-Survey_Memb-Committee-Report.pdf 